\title{
Myasthenia gravis: Anaesthetic implications and considerations-a report of two cases
}

\section{Myastenya gravis: Anestezilk müdahaleler ve görüşler-iki olgu sunumu}

Jatin Lal, Teena Bansal

\author{
Department of Anaesthesiology \& Critical Care Pt. B.D. Sharma University of Health Sciences, Rohtak-124001 \\ (Haryana) India \\ Corresponding author: Dr. Teena Bansal, 2/8 FM, Medical Campus, PGIMS, Rohtak -124001 (Haryana) India \\ E-mail: aggarwalteenu@rediffmail.com \\ Received/Accepted: October 06, 2015 / September 04, 2016
}

Conflict of interest: There is not a conflict of interest.

\begin{abstract}
SUMMARY
Myasthenia gravis is an autoimmune disease characterized by weakness and fatigueability of skeletal muscles with improvement following rest. Perioperative management of such a patient poses a significant challenge to the anaesthesiologist, because it affects the neuromuscular junction. Also, the association of myasthenia gravis with other autoimmune disorders is well known. Preoperative evaluation of the patient includes review of the severity of the patient's disease and the treatment regimen. Optimisation of the condition of the myasthenic patient can markedly decrease the risk of surgery and improve the outcome. Anaesthetic management must be accomplished with the minimal applicable dose of the anaesthetic agents. Because of the unpredictable response to succinylcholine and the marked sensitivity to non depolarizing muscle relaxants, muscle relaxants should be avoided. All patients should be closely monitored postoperatively in the post anaesthesia care unit or surgical intensive care unit, where respiratory support can be immediately reinstituted.
\end{abstract}

Keywords: Myasthenia gravis, anaesthetic implications, anaesthetic management

\section{ÖZET}

Myastenya gravis iskelet kaslarında, dinlenmeyle düzelen zayıflık ve yorgunlukla karakterize otoimmün bir hastalıktır. Böyle bir hastanın perioperatif yönetiminde anesteziyolojistin önemli bir etkisi vardır. Çünkü hastalık nöromuskuler kavşağı etkilemektedir. Aynı zamanda myastenia gravisin diğer otoimmün hastalıklar birlikteliği iyi bilinmektedir. Hastanın preoperatif değerlendirmesi hastalığının şiddetinin gözden geçirilmesi ve tedavi rejimini kapsar. Myasteniya hastasının durumunun optimizasyonu cerrahi riskini anlamlı derecede azaltır ve sonuçlarını iyileştirir. Anestezi uygulaması, anestezik ajanın minimal uygulama dozuyla yapılmalıdır. Süksinil koline karşı öngörülemeyen yanıt ve nondepolarizan kas gevşeticilerine belirgin hassasiyet olabileceği için, kas gevşeticilerden sakınılmalıdır. Tüm hastalar postanestezi ünitesinde ya da cerrahi yoğun bakımda respiratuar desteği hemen sağlayabilecek şekilde yakından monitörüze edilmelidir.

Anahtar sözcükler: Myastenya gravis, anestezi müdahalesi, anestezi yönetimi 


\section{INTRODUCTION}

Myasthenia gravis ( $\mathrm{MG}$ ) is an autoimmune disease characterized by weakness and fatigueability of skeletal muscles with improvement following rest. It may be localized to specific muscle groups or it may be generalized. It is caused by a decrease in the numbers of postsynaptic acetylcholine receptors at the neuromuscular junction which decreases the capacity of the neuromuscular end plate to transmit the nerve signal. ${ }^{1}$ Patients become symptomatic once the number of acetylcholine receptors is reduced to approximately $30 \%$ of normal. The cholinergic receptors of smooth and cardiac muscle have a different antigenicity than skeletal muscle and are not affected by the disease. It's estimated prevalence is 1 in 20000 and affects females more than males. Early surgical management is now considered to be an important therapeutic intervention for most of the patients of MG. We hereby present two case reports of MG successfully managed for thymectomy\& cholecystectomy under general anaesthesia.

\section{CASE REPORT 1.}

A 17 year old female weighing $40 \mathrm{~kg}$ was posted for thymectomy. She was diagnosed with MG one year ago. She presented with generalized weakness, dysphagia, ptosis and diplopia at that time and was put on tablet pyridostigmine $60 \mathrm{mg} 8$ hourly and tablet prednisolone $15 \mathrm{mg}$ once a day. In addition tablet risedronate $30 \mathrm{mg} /$ week was started. Blood pressure was $110 / 60 \mathrm{~mm} \mathrm{Hg}$ and pulse rate was 60/ min regular. On systemic examination, heart sounds were normal and chest was clear bilaterally. Airway examination was unremarkable. Investigations revealed a raised acetylcholine receptor antibody titre 21.07 $\mathrm{nmol} / \mathrm{L}$ ( normal less than $0.25 \mathrm{nmol} / \mathrm{L}$ ). Thyroid function tests and pulmonary function tests were normal. Antithyroid antibodies against thyroid peroxidase were raised to $209.10 \mathrm{U} / \mathrm{ml}$ ( normal less than 60 $\mathrm{U} / \mathrm{ml}$ ). A computerized tomography ( CT) scan of chest showed no evidence of mediastinal mass and airway passage was normal. Her other investigations i.e. haemoglobin, bleeding time, clotting time, urine examination, blood urea, blood sugar, serum electrolytes, chest $\mathrm{X}$ ray and electrocardiography ( ECG) were within normal limits. She had underwent 3 cycles of plasmapheresis.

General anaesthesia was planned for the procedure. She was premedicated with tablet alprazolam $0.25 \mathrm{mg}$ and tablet ranitidine $150 \mathrm{mg}$ in the night and 2 hour before surgery. Her routine medications were continued on the day of surgery. In the operating room, standard monitors were attached. In addition, invasive blood pressure monitoring was established with radial artery cannulation.

Anaesthesia was induced with injection glycopyrrolate $0.2 \mathrm{mg}$, fentanyl $50 \mu \mathrm{g}$ i.v and propofol $80 \mathrm{mg}$ i.v. with increments of sevoflurane in oxygen with neuromuscular monitoring till there was loss of all four responses in train of four ( TOF). Larynx was sprayed with $10 \%$ xylocaine and she was intubated with cuffed endotracheal tube of internal diameter $7 \mathrm{~mm}$ without use of muscle relaxants. Anaesthesia was maintained with sevoflurane $4 \%$ in $67 \%$ nitrous oxide. Infusion of propofol and fentanyl were started at the rate of 40 $\mathrm{mg} /$ hour and $50 \mu \mathrm{g} /$ hour respectively. Neuromuscular monitoring was done to maintain presence of one count in TOF. Surgery lasted for 3 hours and was uneventful. At the completion of surgery, when all four responses in TOF reappeared, sevoflurane was switched off and infusion of propofol and fentanyl was stopped. Patient regained consciousness and adequate muscle power and was extubated after standard criteria for extubation were met. Postoperative course was uneventful.

\section{CASE REPORT 2.}

A 58 year female was posted for cholecystectomy. She was diagnosed with MG one and a half year ago when she presented with generalized weakness and ptosis and was put on tablet pyridostigmine $90 \mathrm{mg} 6$ hourly and prednisolone $20 \mathrm{mg}$ once a day. She had history of hypothyroidism and hypertension. Blood pressure was 140/86 $\mathrm{mm} \mathrm{Hg}$ and pulse was 
76/min. Systemic examination and airway examination was unremarkable. Routine blood investigations including chesy $\mathrm{x}$ ray, thyroid function tests and pulmonary function tests were normal. Acetylcholine receptor antibody titre was $19.14 \mathrm{n} \mathrm{mol} / \mathrm{L}$. CECT chest revealed no evidence of mediastinal mass. She was on tablet eltroxin $25 \mu \mathrm{g}$ and telmisartan $40 \mathrm{mg}$ once a day.

General anaesthesia was planned for the procedure. She was premedicated with tablet alprazolam $0.25 \mathrm{mg}$ and ranitidine $150 \mathrm{mg}$ in the night and 2 hours before surgery. Her routine medications were continued on the day of surgery. Induction was done with glycopyrrolate $0.2 \mathrm{mg}$, fentanyl $80 \mu \mathrm{g}$, propofol $80 \mathrm{mg}$ with increments of sevoflurane in oxygen and after achieving adequate depth of anaesthesia, Proseal Laryngeal Mask Airway (PLMA) of size 3 was inserted. Anaesthesia was maintained with sevoflurane $2-4 \%$ in $67 \%$ nitrous oxide. At the completion of surgery, PLMA was removed. Intraoperative and postoperative course was uneventful.

\section{DISCUSSION}

Perioperative management of a patient with MG poses a significant challenge to the anaesthesiologist, because it affects the neuromuscular junction. Also, the association of MG with other autoimmune disorders such as thyrotoxicosis, hypothyroidism, hypokalemic periodic paralysis, rheumatoid arthritis, sjogren's syndrome, systemic lupus erythmatosis and diabetes mellitus is well known. ${ }^{2}$

Preoperative evaluation of the patient with MG includes review of the severity of the patient's disease and the treatment regimen. Specific attention should be paid to voluntary and respiratory muscle strength. The patient's ability to protect and maintain a patent airway postoperatively may be compromised if any bulbar involvement exists preoperatively. The ability to cough and clear secretions may be compromised as well. Respiratory muscle strength can be quantified by pulmonary function tests ( negative inspiratory pressure and forced vital capacity). These tests may be necessary as a reference to determine the optimal conditions for extubation postoperatively as well as the need for postoperative mechanical ventilation. ${ }^{3,4}$ The patient should be thoroughly evaluated for other associated autoimmune diseases.

A chest $X$ ray is indicated to determine the presence of aspiration or other pneumonias, which commonly occur in patients with MG. A CT scan or magnetic resonance imaging ( MRI) is indicated to detect thymoma. If a thymoma presents an anterior mediastinal mass, intrathoracic airway or vascular obstruction may occur upon induction of anaesthesia. Flow volume loops may be indicated preoperatively. Maximal inspiratory and expiratory flow volume loops obtained with the patient in the supine and upright positions will measure the extent of the respiratory impairment as well as whether the impairment is fixed or dynamic. ${ }^{1}$

Optimisation of the condition of the myasthenic patient can markedly decrease the risk of surgery and improve the outcome. The perioperative management of myasthenic patient will be influenced by the surgical procedure and the preferences of the surgeon and the anaesthesiologist. Some choose to omit anticholinesterase on the morning of surgery to decrease the need of drug for muscle relaxants. ${ }^{5} \mathrm{We}$ decided to continue anticholinesterase drug on the morning of surgery for psychological support of the patient. Steroid was also given preoperatively as steroid dependent patients require perioperative coverage.

Patients with MG show resistance to deporarising agents. It is probable that the requirements are increased due to the loss of receptors, because these agents create neuromuscular block by agonist action. The $\mathrm{ED}_{95}$ of succinylcholine in $\mathrm{MG}$ patients is 2.6 times that in non myasthenic patients ( $0.8 \mathrm{mg} / \mathrm{kg}$ vs $0.3 \mathrm{mg} / \mathrm{kg}) .{ }^{6}$ Myasthenic patients are more likely than normal patients to develop a phase II block. In addition, cholinesterase inhibition caused by pyridostigmine given preoperatively may affect the metabolism of succinylcholine resulting in prolonged block. ${ }^{7}$ Themyasthenic patient is typically sensitive to non depolarizing neuromuscular blockers. Sensitivity to non depolarizing agents has been described in patients with minimal disease ( ocular 
symptoms only), in those in apparent remission or those with subclinical undiagnosed myasthenia. ${ }^{8}$ Because of the unpredictable response to succinylcholine and the marked sensitivity to non depolarizing muscle relaxants, we avoided muscle relaxants and decided to induce the patient on deep inhalational anaesthesia. These agents allow neuromuscular transmission to recover with rapid elimination of these agents at the end of surgery. The use of muscle relaxants in patients with MG has been associated with a higher rate of unsuccessful extubation at the end of surgery and with longer postoperative ventilation and hospital stay.

Sevoflurane is the inhalational agent of choice for induction and maintenance due to its physical properties of low blood solubility, pleasant odour and less irritation to the airway. ${ }^{9}$ Propofol has the theoretic advantages of short duration of action without effect on neuromuscular transmission. So we used propofol with sevoflurane for rapid induction, better relaxation of jaw muscles and for providing adequate depth of anaesthesia. Sevoflurane has been used as the sole anaesthetic agent for a transsternal thymectomy. ${ }^{10}$

The introduction of short acting opioids makes these drugs more titrable in the myasthenic patients. Remifentanil's short elimination half life makes this drug appealing. ${ }^{11}$ But remifentanil was not available in our O.T., so we used fentanyl for analgesia in addition to non steroidal anti-inflammatory drugs.

All patients with MG should be closely monitored postoperatively in the post anaesthesia care unit or surgical intensive care unit, where respiratory support can be immediately reinstituted ${ }^{1}$.

To conclude, MG is a disease with many implications for the safe administration of anaesthesia. Its anaesthetic management must be accomplished with the minimal applicable dose of the anaesthetic agents and the patient must be observed carefully.

\section{REFERENCES}

1. Abel M, Eisenkraft JB. Anesthetic implications of myasthenia gravis. The mountsinai journal of medicine 2002; 69: 31-7.
2. Datt V, Tempe DK, Singh B, Tomar AS, Banerjee A, Dutta D, et al. Anesthetic management of patient with myasthenia gravis and uncontrolled hyperthyroidism for thymectomy. Ann Card Anaesth 2010; 13: 49-52.

3. Naguib M, El- dawlatly AA, Ashour M, Bamgboye EA. Multivariate determinants of the need for postoperative ventilation in myasthenia gravis. Can J Anaesth 1996; 43: 100613.

4. Leventhal SR, Orkin FK, Hirsh RA. Prediction of the need for postoperative mechanical ventilation in myasthenia gravis. Anesthesiology 1980; 53: 26-30.

5. Baraka A, Taha S, Yazbeck V, Rizkallah P. Vecuronium block in the myasthenicpatient. Influence of anticholinesterase therapy. Anaesthesia 1993; 48: 588-90.

6. Eisenkraft JB, Book WJ, Mann SM, Papatestas AE, Hubbard M. Resistance to succinylcholine in myasthenia gravis: A dose- response study. Anesthesiology 1988; 69: 760-3.

7. Baraka A. Suxamethonium block in the myasthenic patient. Correlation with plasma cholinesterase. Anaesthesia 1992; 47: 217-9.

8. Kim JH, Mangold J. Sensitivity to both vecuronium and neostigmine in a seronegative myasthenic patient. $\mathrm{Br} \mathrm{J}$ Anaesth 1989; 63: 497-500.

9. Dubey SR, Shah NP, Patel HJ, Swadia VN, Agrawal D, Gandhi A. Anaesthetic management of a patient with myasthenia gravis in a known case of hyperthyroidism and bronchial asthma posted for thymectomy- a case report. Indian J Anaesth 2004; 48: 59-61.

10.Kiran U, Choudhury M, Saxena N, Kapoor P. Sevoflurane as a sole anaesthetic agent for thymectomy in myasthenia gravis. Acta Anaesthesiol Scand 2000; 44: 351-3.

11. Bansal T, Hooda S. Newer drugs in anaesthesia. Int J Pharm PharmSci 2012; 4: 668-70. 